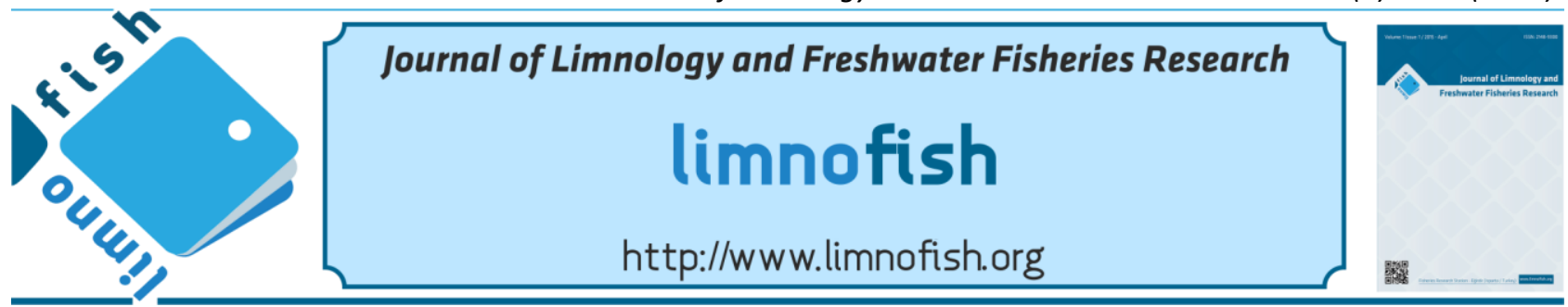

\title{
Limnochemistry and Biological Characteristics of Small High Altitude Reservoirs in a Sub-Tropical Region, Nyanga, Zimbabwe
}

\section{Tamuka NHIWATIWA}

University of Zimbabwe Department of Biological Sciences Harare, Zimbabwe

\begin{abstract}
A B STRACT
The ecological characteristics of ten small reservoirs in the high-altitude Eastern Highlands region of Zimbabwe, were studied. Water quality and sediment quality for a range of parameters and also the phytoplankton, zooplankton, macrophyte communities were described. The water quality of the reservoirs was in near pristine condition and their trophic status was oligotrophic and ultra-oligotrophic. In contrast, the sediments especially of the Connemara reservoirs had unusually high levels of phosphorus. Given the high levels of dissolved oxygen in the reservoirs, most phosphorus is likely to be bound to the sediment but its present source was not immediately clear. Phytoplankton densities were very low indicative of low productivity. The major phytoplankton taxa identified included Cyanophyta, Euglenophyta, Chrysophyta, Bacillariophyceae, Pyrrophyta and Chlorophyta. The least abundant taxa were the Euglenophyta while the most abundant was the Chlorophyta. Zooplankton taxa comprised of Daphniidae, Chydoridae, Bosminidae, Sididae, Macrothricidae, Cyclopoida and Calanoida. The daphniids were the most abundant species, while the rotifers were not identified further in this study. Several macrophyte species were identified but the reservoirs showed low similarity in macrophytes composition. There were no clear environmental gradients to explain the patterns. The results of this study provide an important baseline from which future studies especially on the impact of climate change and landuse can be assessed.
\end{abstract}

Keywords: Small dams, montane, limnology, phytoplankton, zooplankton
ARTICLE INFO

\section{RESEARCH ARTICLE}

$\begin{array}{lll}\text { Received } & : 14.08 .2016 \\ \text { Revised } & : 12.01 .2017 \\ \text { Accepted } & : 25.01 .2017 \\ \text { Published } & : 24.04 .2017\end{array}$

DOi: $10.17216 /$ LimnoFish.288101

* CORRESPONDING AUTHOR

drtnhiwatiwa@gmail.com

Tel : +263772439922

How to Cite

Nhiwatiwa T. 2017. Limnochemistry and Biological Characteristics of Small High Altitude Reservoirs in a Sub-Tropical Region, Nyanga, Zimbabwe. LimnoFish. 3(1): 1-13. doi: 10.17216/LimnoFish.288101

\section{Introduction}

Lakes and reservoirs are important habitats providing valuable ecosystem services throughout the world. However, increasing human populations have result in an accelerated demand on water supplies for domestic, industrial and agricultural use (Brönmark and Hansson 2002). The predicted global human population increase which is linked with rapid economic development will in the near future result in the limited availability of freshwater resources. The lack of enough of water resources is therefore predicted as one of humankind greatest problem to resolve in this century (Johnson et al. 2001). Furthermore, freshwater systems have been severely affected by a many other anthropogenic disturbances, which have led to serious negative effects on the structure and function of these ecosystems (Brönmark and Hansson 2002). Hence, there is a need to fully understand how these ecosystems function before they are irreversibly degraded.

The small reservoirs in Nyanga (Eastern Highlands region) are located at high altitude and have relatively cool, ultra-oligotrophic waters. Some investigations have been carried out in the reservoirs in Nyanga but they all tend to be superficial in their approach. The most detailed study was that of Nduku and Robarts (1977) who investigated water chemistry in the Connemara reservoirs. The sediments of Connemara 3 dam were very rich in nutrients (nitrogen \& phosphorus) and comparable to those of highly eutrophic systems like Lake Chivero (Nduku and Robarts 1977) but the water was oligotrophic despite receiving effluent via underground streams from septic tanks built for cottages dotting the lake. This paradox was attributed to the geochemistry of the area which consists of mainly dark dolerite rock 
(Nduku and Robarts 1977) which leads to the release of large amounts of iron and manganese when it weathers. These cations complex the reactive phosphorus in the water and 'lock' it in the sediments in an insoluble form thus making it unavailable for use by the algae. The lake was also fully oxygenated at all times and phosphorus was locked to the sediments in an insoluble form. It is believed that this phenomenon had prevented eutrophication of these lakes by septic tanks of the cottages that surround them (Nduku and Robarts 1977).

Thornton and Cotterill (1978) also gave some details on the water chemistry and aspects of the plankton populations in a general limnological survey of the reservoirs in the national Park. Green (1990) sampled nine Nyanga reservoirs as part of a general survey of the zooplankton of some reservoirs along the Eastern watershed of Zimbabwe and the effect of altitude on the species composition. This survey found that zooplankton in the Connemara and Troutbeck reservoirs was significantly different from that of the other reservoirs. No explanation was given for this and it is not clear if these differences were caused by high altitude or the fact that they are on a different river system or because of differences in water chemistry. High altitude lakes are very diverse and examples of studies elsewhere include Andean lakes in South (Mühlhauser et al. 1995; Jorge et al. 2009); high altitude regions of Africa such as Kenya (Mwaura et al. 2002) and Ethiopia (Elizabeth et al. 1992); and alpine lakes (Mosello 1984); and even including lakes in the Himalayas (Tartari et al. 1998). The local differences among high latitude lakes make it difficult to make generalisations, and therefore each system has to be studied.

In Zimbabwe, thousands of reservoirs have been constructed to supply the water demands of industry, agriculture and the rapidly growing human urban population. National statistics estimate that there are about 12000 small $\left(<10\right.$ ha or $\left.106 \mathrm{~m}^{3}\right)$ reservoirs covering an area about 126 089ha (Ersal 1994). About $80 \%$ of the 10747 listed reservoirs in Zimbabwe are $<5$ ha in area. The majority of these reservoirs $(61 \%)$ are situated in the former commercial farming areas, with $25 \%$ in communal lands and 14\% in resettlement areas (Ersal 1994). This distribution reflects the high demand for water for large-scale agriculture (Ersal 1994). However, until recently very little was known about the limnology of small reservoirs (Nhiwatiwa and Marshall 2006, 2007).

This study aims to increase our understanding of limnological characteristics of high altitude waterbodies, which have not yet been studied in much detail. The results will also form an important baseline against which to measure future changes that might take place in them. When this study was done, issues around climate change were not so topical then compared to the present, and for these sensitive systems it is important to have on record their ecological status to monitor for future changes. The main objective was therefore to investigate a number of reservoirs in order to determine the relationships between water chemistry, phytoplankton and zooplankton. Sediments were also analysed to explore the relationship between catchment geology and sediment chemistry.

\section{Study area}

Nyanga in situated in Zimbabwe's Eastern highlands with the highest altitude of all the regions of this country (> $1500 \mathrm{~m}$ a.s.l.). It has a montane climate with high annual rainfall $>800 \mathrm{~mm}$ annually and very cold winters $\left(10-16^{\circ} \mathrm{C}\right)$. Ten small montane reservoirs in the Nyanga area were chosen for this study. Reservoirs on the Nyangombe River were located in the Rhodes Nyanga National Park while those on the Tsanga River were situated in community areas (Figure 1). Some morphometric characteristics of the reservoirs are presented in Table 1. The reservoirs are mainly used for recreation, irrigation and domestic water supply.

\section{Materials and Methods \\ Water quality}

The study was done in July 2003 for a two week period. Six sampling sites were randomly selected in each reservoir: 3 in the pelagic and 3 in the littoral zones. A 3-litre van Dorn sampler was used to collect water samples at $0.5 \mathrm{~m}$ depth intervals to produce a depth integrated sample of $18 \mathrm{~L}$ per sampling site. The samples were mixed (vertical series) and subsamples taken for field and laboratory analyses. Conductivity \& total dissolved solids, $\mathrm{pH}$, and transparency were measured with a conductivity meter (WTW LF330), a $\mathrm{pH} / \mathrm{mv}$ meter (WTW pH 330) and a 20-cm diameter Secchi disc, respectively.

Water quality chemical variables were measured with a HACH water analysis kit (DR/2010 portable data logging spectrophotometer) using filtered water samples (Whatman GF 47mm filters) except for total nitrogen and total phosphorus. The summary of each method is given but they are described in detail in Farber et al. (1960): Chemical oxygen demand, determined by the reactor digestion method (No.8000); Nitrate-nitrogen by the chromotropic acid method (No. 10020); nitrite by the diazotization (chromotropic acid) method (No. 8507); ammonia by the salicylate method (Method 10023), and total nitrogen by persulfate digestion (No. 10071); Reactive and total phosphorus were determined by the Phos Ver 3 (No. 8048) and the PhosVer 3 with 


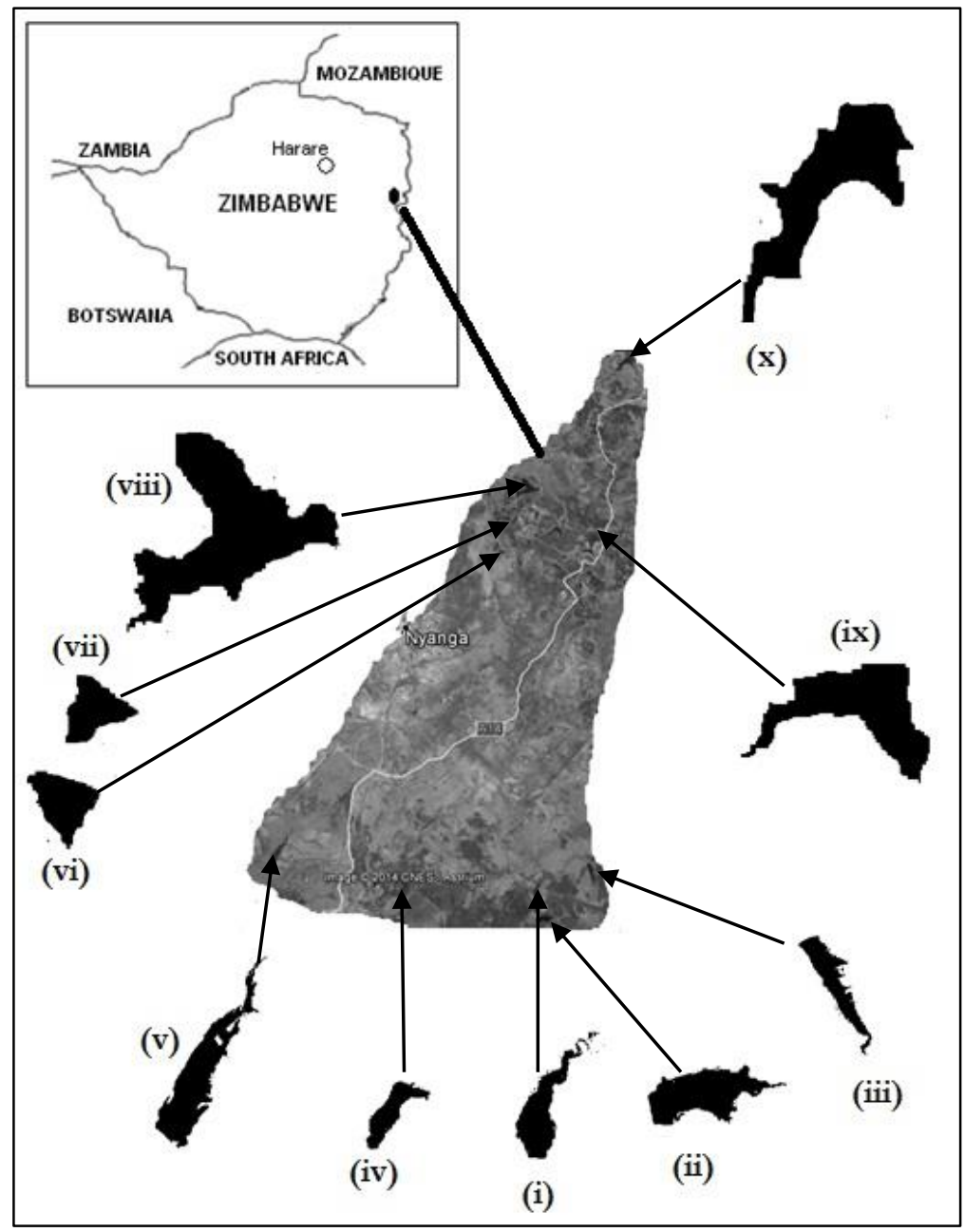

Figure 1. Map of Nyanga and the ten small montane reservoirs that were sampled in this study. (Insert: Map of Zimbabwe). . (Gul = Gulliver (i); Mar = Mare (ii); Pur = Purdon; Rho = Rhodes (iv); Udu = Udu (v); Con I, 2, $3=$ Connemara I, 2, 3 (vi, vii \& viii); Tro = Troutbeck (ix); Sto I = Storer I (x).

acid persulfate digestion methods (No. 8190) respectively.

\section{Sediment}

Sediment analysis was done at Institute of Environmental Soil Science laboratory at the University of Zimbabwe. The variables analysed in units of $\left(\mu \mathrm{g} \mathrm{g}^{-1}\right.$ of sediment) include soil $\mathrm{pH}$, ammonium- $\mathrm{N}$, nitrate- $\mathrm{N}$, total available nitrogen, total organic carbon, total nitrogen, total phosphorus, available phosphorus, calcium $(\mathrm{Ca})$, magnesium $(\mathrm{Mg})$, potassium $(\mathrm{K})$, sodium $(\mathrm{Na})$, iron $(\mathrm{Fe})$ and manganese $(\mathrm{Mn})$. Metal concentrations in water were analysed in the laboratory using Flame Atomic Absorption Spectrophotometry (FAAS) (Greenberg 1980). The water samples were first filtered through Whatman $\mathrm{G} / \mathrm{F}$ filters and then acidified with nitric acid to $\mathrm{pH}$ less than 2 . The water sample was then aspirated into a flame and atomized.

Metals in the sediments were also analysed using the Flame Atomic Absorption Spectrophotometry method (FAAS) (Greenberg 1980). The acid digestion method was used to extract the metals from the sediments for quantification by the FAAS. This procedure consisted of two parts: I. Digestion: the sediments were oven dried at $180^{\circ} \mathrm{C}$ in a muffle furnace and large aggregates were broken up. Then $20 \mathrm{ml}$ of nitric acid and $5 \mathrm{ml}$ of perchloric acid were added to $5 \mathrm{~g}$ of the oven dried sample. The mixture was then heated on a hot plate until fumes were produced and allowed to cool to room temperature. 2 . Acidification: $20 \mathrm{ml}$ of $50 \%$ hydrochloric acid was added to the mixture from the first digestion. The acidified mixture was heated until boiling and then was cooled to room temperature. The acidified mixture was filtered and distilled water was added to the filtrate in a volumetric flask up to the 100 millimetre mark. The digested sediments were then analysed for metal amounts in an Atomic Absorption Spectrometer (Greenberg 1980).

Quality control was assured by the use of procedural blanks and standards. A known concentration of the standard solution was assayed after every ten samples to verify the analytical quality of the result since there was no standard reference material available. In all the cases for sediments and 


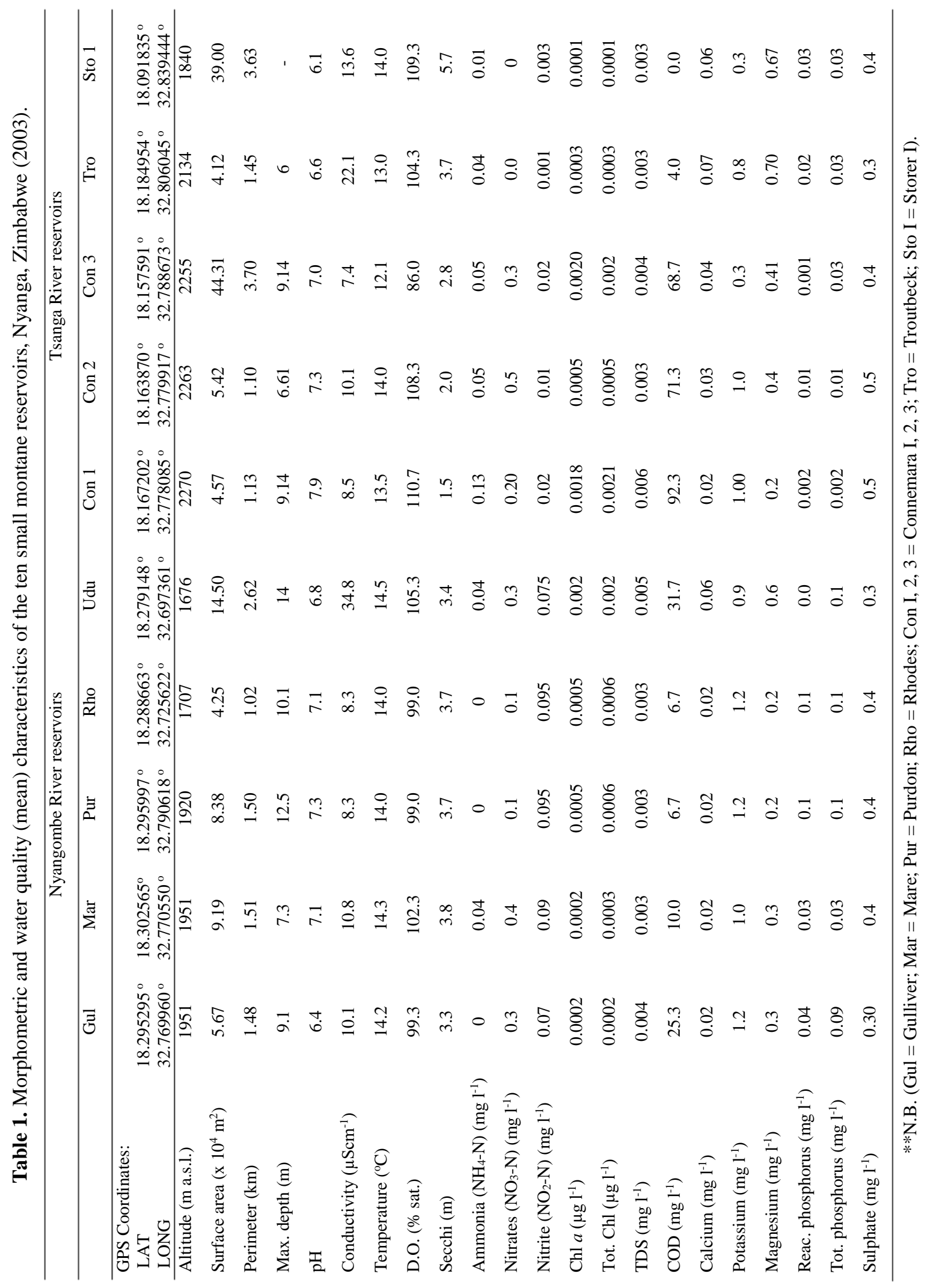


water, a preparation / reagent blank was prepared for every 20 samples and all the concentrations were below the detection limits. Each sample was analyzed in triplicate for repeatability with a relative standard deviation $<5 \%$ for all the metals analyzed.

Concentrations of nickel copper, cadmium lead, iron zinc and chromium were then determined using FAAS (Greenberg 1980).

\section{Plankton}

A subsample of $5 \mathrm{~L}$ was taken from the well mixed depth integrated sample and passed through a net of mesh size $64 \mu \mathrm{m}$. In addition, qualitative horizontal and vertical net hauls were taken at littoral and limnetic region in each reservoir. The zooplankton samples were preserved in 10\% formaldehyde. These samples were taken to the laboratory were identification and enumeration were done under the microscope. Cladocerans were identified to species using keys in Rey and Saint-Jean (1980), Seaman et al. (1999) and Fernando (2002). Unfortunately it was not possible to identify copepods to species level and rotifers were not included in the analysis. Total chlorophyll and Chlorophyll $a$ were analysed as an indication of phytoplankton biomass in each of the reservoirs. Subsamples of $300 \mathrm{ml}$ were collected in plastic bottles and these were later filtered using Whatman GF $47 \mathrm{~mm}$ filter paper. Analysis was done by the method described by Bronmark and Hansson (1998). Identification of phytoplankton was only done to Class level using keys in Prescott (1970), Elenbass (1994) and Canter-Lund and Lund (1995).

\section{Macrophytes}

The detailed macrophyte flora of each reservoir was surveyed by wading in the shallows and by boats for the deep water. Wading was done in a zigzag manner across the littoral zone length, frequently investigating all the habitat types present. At sites where the water was too deep to wade, a boat was used. Samples were collected and those that could not be identified on site were preserved in plant pressed for future processing and verification. Identification of the macrophytes was taken to species level where possible, using field identification guides by Sainty and Jacobs (1988). Preserved samples were alos later verified using identification guides by Gerber et al. (2004) and Cook (2004).

\section{Data analysis}

Principal Component Analysis (PCA) in the program CANOCO (version 3.12) was used to determine correlative relationships among the ten reservoirs for water and sediment quality and sediment chemical variables were examined using. To reduce skewness because of different measuring units, all the variables were log transformed. Principal Component Analysis analysis was done in two stages: for the water quality variables and then the sediment variables. The analysis for water quality was done for 17 physico-chemical variables and these were conductivity, $\mathrm{pH}$, total dissolved solids, Secchi disc transparency, chemical oxygen demand, reactive phosphorus, total chlorophyll, nitrate-N, ammonia-N, nitrite- $\mathrm{N}$, total phosphorus, water temperature, dissolved oxygen, calcium, potassium, magnesium and sulphate. Principal Component Analysis (PCA) for the sediment quality was done for 14 variables which were $\mathrm{pH}$, ammonium- $\mathrm{N}$, nitrate, total available nitrogen, total organic carbon, total nitrogen, total phosphorus, available phosphorus and the cations iron, manganese, calcium, magnesium, potassium and sodium.

Significant differences between the reservoirs in water and sediment quality were first tested with Kruskal-Wallis Anova at 5\% significance level. Then pairwise comparisons were done using MannWhitney tests at 5\% significance level, with Bonferonni corrected and uncorrected measures. The programme STATISTICA (ver 10) was used for the analysis. Cluster analysis was done for water quality, sediment quality and macrophyte species composition using the PRIMER statistical package (PRIMER-E, 2000) based on a similarity matrix of normalized Euclidean distances.

\section{Results}

\section{Water quality}

The results of the water quality assessments for the ten reservoirs are presented in Table 1 . The $\mathrm{pH}$ did not vary much across the reservoirs being near neutral ranging from 6.1 in Storers I to 7.9 in Connemara 3. Since sampling was done in winter, temperatures were very low being less than $15^{\circ} \mathrm{C}$ while dissolved oxygen showed conditions close to super saturation $(>100 \%)$ for most of the reservoirs, typical of oligotrophic systems. Water clarity measured by the Secchi disc was in most reservoirs < 4 but was uncharacteristically low in Connemara I dam $(1.5 \mathrm{~m})$. Conductivity was exceptionally low with most reservoirs about $10 \mu \mathrm{S} \mathrm{cm}^{-1}$ or less which is near distilled water, while the highest conductivity was measured in Udu dam $\left(34.8 \mu \mathrm{Scm}^{-1}\right)$. Similarly total dissolved solids were extremely low $(<0.001$ $\mathrm{mgl}^{-1}$ ) and the pattern across reservoirs matched that of conductivity. Chemical oxygen demand was rather variable among the reservoirs with some reservoirs recording $0 \mathrm{mgl}^{-1}$ while the Connemara reservoirs recorded the highest values $>65 \mathrm{mgl}^{-1}$. 
Cations and anions were also measured in the reservoirs. Calcium $(\mathrm{Ca})$ ranged from 0.02 to 0.09 $\mathrm{mgl}^{-1}$ while potassium $(\mathrm{K})$ was in most reservoirs around $1 \mathrm{mgl}^{-1}$ and about 2 magnitudes greater than calcium. Magnesium concentrations were about a magnitude lower than potassium with most values in the range of $0.3-0.5 \mathrm{mgl}^{-1}$ and higher values were above $0.6 \mathrm{mgl}^{-1}$. Sulphates did not vary much among the reservoirs ranging between $0.3-0.5 \mathrm{mgl}^{-1}$. Nutrients comprising nitrogen and phosphorus fractions were also measured in the reservoirs. Reactive phosphorus concentrations were highest in the Nyangombe reservoirs Purdon, Rhodes and Udu reservoirs while the lowest values were measured in the Connemara reservoirs. A similar pattern was observed for total phosphorus concentrations with sometimes very small differences between reactive and total phosphorus concentrations. Ammonianitrogen concentrations were highest in the Connemara reservoirs but were undetectable in some of the reservoirs such as Purdon and Rhodes. Total chlorophyll and chlorophyll $a$ were of very low concentrations suggesting low algal biomass in the reservoirs. Overall, there were no significant differences in water quality among the reservoirs (Kruskal-Wallis Anova, $\mathrm{p}>0.05$ ) and none of the pairwise comparisons were significantly different (Mann-Whitney, $\mathrm{p}>0.05$ ).

Principal Components Analysis (PCA) results showed that the first two axes (axis $1 \& 2$ ) accounted for $59 \%$ of the patterns in the environmental factors for the ten small reservoirs (Figure 2). The first axis explained $34.5 \%$ while the second axis explained for $24.5 \%$ of the variation. The factor loadings indicated that the first PC axis was characterised by a larger number of environmental parameters (with factor loading > $|0.50|)$ than the second PC axis. The parameters with positive factor loadings on $\mathrm{PC}$ axis 1 were $\mathrm{pH}$, ammonia-nitrogen, nitrate-nitrogen, total chlorophyll, TDS, COD and sulphates. Negative factor loadings on PC axis 1 were recorded for Secchi disk transparency and calcium. On PC axis 2, positive factor loadings were recorded for nitrite-nitrogen and magnesium, while negative factor loadings were recorded for ammonium, total organic carbon and total phosphorus. Only iron had factor loading > $|0.50|$ on PC axes $3 \& 4$.

The plot of the first and second PCs showed patterns which linked the different site characteristics to sediment parameters measured. In the first upper right quadrat, there was Gulliver and Rhodes dams which were characterized by increasing ionic content of metal ions $\mathrm{Na}, \mathrm{Mg}$ and $\mathrm{Ca}$ (Figure 3). Connemara $1 \& 3$ dams were in the right lower quadrat and were characterized by higher nutrient concentrations of ammonium, total nitrogen, total phosphorus and total organic matter (Figure 2). The lower left quadrat had all the remaining sites which suggested that they were all similar in their overall water quality characteristics (Figure 2).

\section{Sediment}

Sediments were assessed for several soil parameters and the results are presented in Table 2. Sediment $\mathrm{pH}$ was generally acidic in the reservoirs. Ammonium-nitrogen and total available nitrogen concentrations differed slightly and the trends that emerged among the reservoirs showed that Connemara $1 \& 3$, and Troutbeck reservoirs (all Tsanga River reservoirs) had the highest concentrations, while the least concentration was in Mare dam. Nitrate concentrations were generally low ranging from undetectable $(0 \mathrm{ppm})$ to $0.97 \mathrm{ppm}$ in Mare dam. Total nitrogen was highest in the sediments of Connemara 3 (8.43 ppm) and Gulliver (9.37 ppm) reservoirs. Available phosphorus concentrations were relatively low in all the reservoirs $(0.09-0.22 \mathrm{ppm})$ which was in contrast to the total phosphorus concentrations. Total phosphorus concentrations were several magnitudes higher than those of available phosphorus were measured ranging from $120-896 \mathrm{ppm}$. The highest sediment phosphorus concentrations were recorded in Connemara 3 and the least concentration in Udu dam. Connemara 2 had total phosphorus concentrations of $522 \mathrm{ppm}$ and $550 \mathrm{ppm}$, respectively.

Calcium (Ca) had relatively higher concentrations compared to the others cations. The lowest concentrations were recorded in Connemara I $\& 2$ and Purdon reservoirs $(\approx 50 \mathrm{ppm})$ and the highest in Gulliver dam (198 ppm). Iron (Fe) and Manganese $(\mathrm{Mn})$ were all less than $0.25 \mathrm{ppm}$ with higher concentrations of $\mathrm{Fe}$ in Rhodes reservoirs while $\mathrm{Mn}$ concentrations were comparable among the reservoirs (Table 2). Magnesium (Mg) concentrations varied widely among the reservoirs ranging from undetectable $(0 \mathrm{ppm})$ to as high as 55 ppm. The highest value was in Gulliver dam while the least values were in Troutbeck. Potassium (K) concentrations ranged from $2-13.4 \mathrm{ppm}$ with highest concentrations in Gulliver dam. Sodium (Na) concentrations in the reservoirs ranged from 12.7 $36 \mathrm{ppm}$, and again Gulliver dam had the highest concentrations while the least were in Storers I dam, a pattern similar to that of $\mathrm{K}$ and $\mathrm{Mg}$.

\section{Ordination analysis results}

Principal Components Analysis (PCA) showed that the first two axes cumulatively explained $64.4 \%$ of the variation among the reservoirs in sediment characteristics Figure 3. Axis 1 accounted for the 
most variation with $34.8 \%$ while the second axis accounted for $29.6 \%$ of the variation. The factor loadings indicated that the first PC axis was defined by a larger number of environmental parameters (with factor loading $>|0.50|$ ) than the second PC axis. The parameters with positive factor loadings on PC axis 1 were total organic carbon, total nitrogen, calcium, magnesium, potassium and sodium. Negative factor loadings on PC axis 1 were recorded for available phosphorus and $\mathrm{pH}$. On PC axis 2, positive factor loadings were recorded for nitrate and magnesium, while negative factor loadings were recorded for ammonium, total organic carbon and total phosphorus. Only iron had factor loading > $|0.50|$ on PC axes $3 \& 4$.

The plot of the first and second PCs shows patterns which linked the different site characteristics to sediment parameters measured. In the first upper right quadrat, there was Gulliver and Rhodes dams which were closely related to increasing ionic content

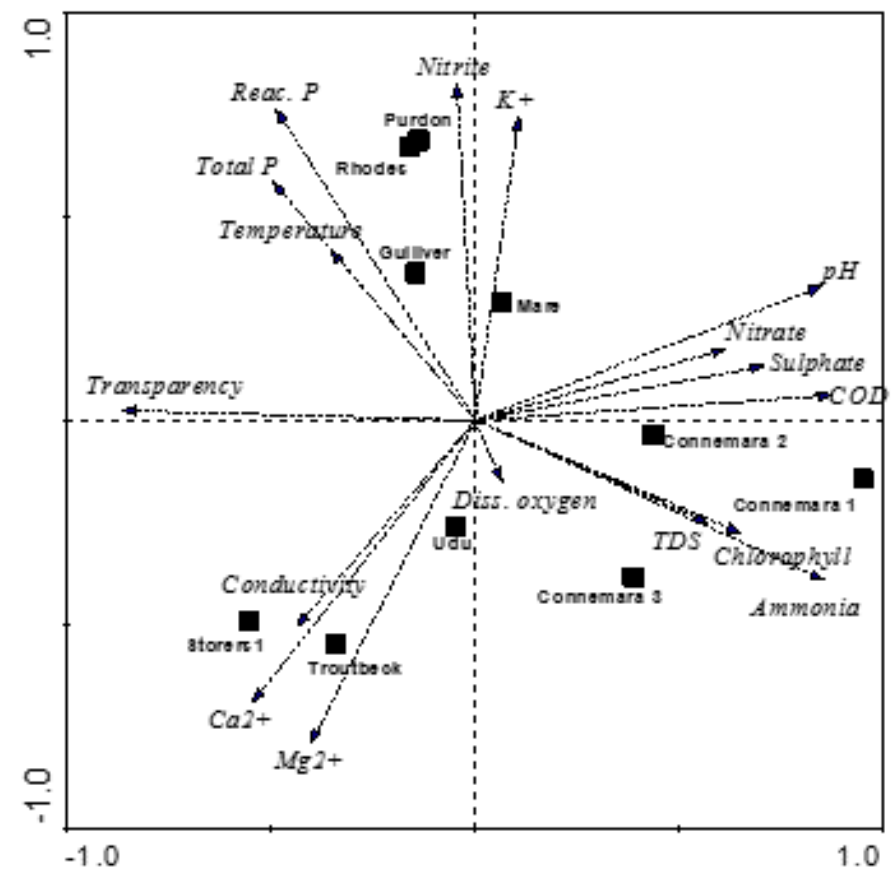

Figure 2. Principal Components Analysis (PCA) ordination plot of environmental variables in ten small montane reservoirs, Nyanga, Zimbabwe (2003).

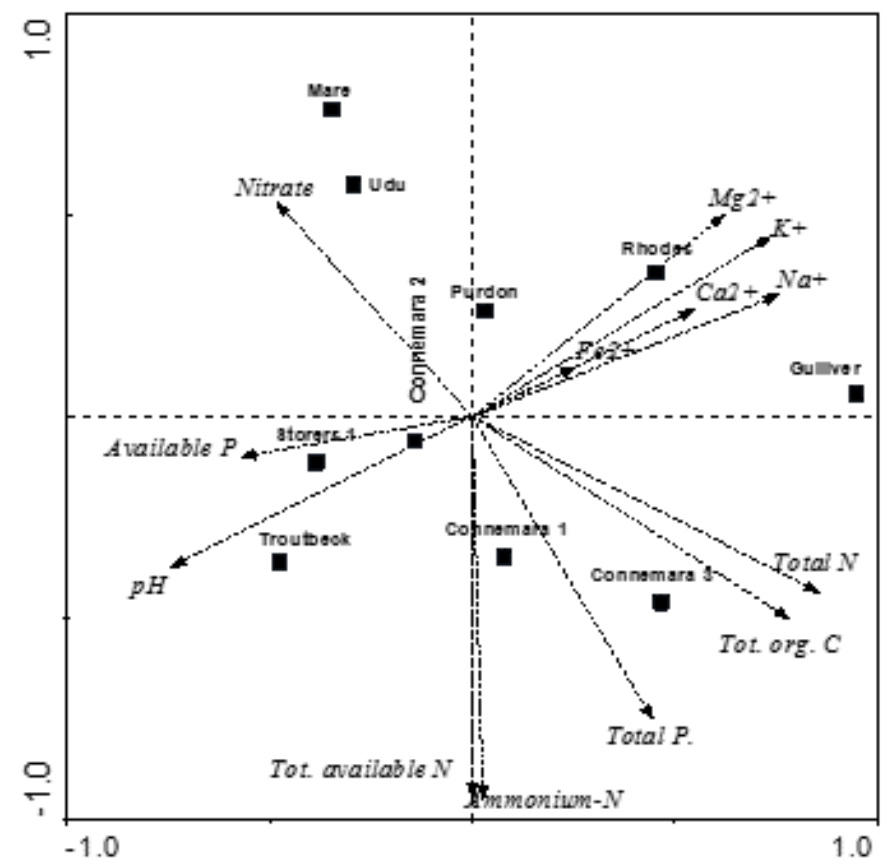

Figure 3. Principal Components Analysis (PCA) ordination plot showing the sediment characteristics of ten small montane reservoirs, Nyanga, Zimbabwe (2003). 
Table 2. Sediment characteristics of the ten small montane reservoirs, Nyanga, Zimbabwe (2003).

\begin{tabular}{lcccccccccc}
\hline & \multicolumn{4}{c}{ Nyangombe River reservoirs } & \multicolumn{5}{c}{ Tsanga River reservoirs } \\
\hline Variable & Gul & Mar & Pur & Rho & Udu & Con 1 & Con 2 & Con 3 & Tro & Sto 1 \\
pH & 4.8 & 5.5 & 4.6 & 4.8 & 5.5 & 4.9 & 5.5 & 5.2 & 6.1 & 6.1 \\
Ammonium N $(\mu \mathrm{g} / \mathrm{g})$ & 17.47 & 9.57 & 12.50 & 12.40 & 12.43 & 28.23 & 14.63 & 28.68 & 26.83 & 17.87 \\
Nitrate $(\mu \mathrm{g} / \mathrm{g})$ & 0.01 & 0.97 & 0.37 & 0.01 & 0.43 & 0.01 & 0.30 & 0.38 & 0.27 & 0.43 \\
Total available nitrogen $(\mu \mathrm{g} / \mathrm{g})$ & 17.47 & 10.50 & 12.80 & 12.40 & 12.87 & 28.23 & 14.90 & 29.06 & 27.07 & 18.23 \\
Total organic carbon $(\mathrm{mg} / \mathrm{g})$ & 106.17 & 28.33 & 46.33 & 45.10 & 24.80 & 45.20 & 48.20 & 90.31 & 40.33 & 46.37 \\
Total nitrogen $(\mathrm{mg} / \mathrm{g})$ & 9.37 & 1.40 & 3.00 & 3.13 & 1.37 & 4.47 & 3.42 & 8.43 & 1.80 & 2.50 \\
Total phosphorus $(\mu \mathrm{g} / \mathrm{g})$ & 456.67 & 176.67 & 336.67 & 440.00 & 120.00 & 383.33 & 521.67 & 896.67 & 336.67 & 413.33 \\
Available P $(\mu \mathrm{g} / \mathrm{g}))$ & 0.09 & 0.18 & 0.09 & 0.12 & 0.09 & 0.12 & 0.13 & 0.12 & 0.22 & 0.20 \\
Iron $(\mathrm{Fe})(\mu \mathrm{g} / \mathrm{g})$ & $\mathrm{ND}$ & 0.02 & $\mathrm{ND}$ & 0.44 & 0.01 & $\mathrm{ND}$ & 0.12 & 0.14 & $\mathrm{ND}$ & 0.19 \\
Manganese $(\mathrm{Mn})(\mu \mathrm{g} / \mathrm{g})$ & 0.09 & 0.18 & 0.09 & 0.12 & 0.09 & 0.12 & 0.13 & 0.12 & 0.22 & 0.2 \\
Calcium $(\mathrm{Ca})(\mu \mathrm{g} / \mathrm{g})$ & 198.40 & 109.55 & 50.77 & 128.26 & 106.88 & 52.10 & 49.77 & 112.22 & 71.48 & 82.83 \\
Magnesium $(\mathrm{Mg})(\mu \mathrm{g} / \mathrm{g})$ & 54.78 & 24.05 & 2.00 & 20.71 & 16.70 & 9.35 & 2.67 & 24.22 & $\mathrm{ND}$ & 11.36 \\
Potassium $(\mathrm{K})(\mu \mathrm{g} / \mathrm{g})$ & 13.36 & 8.02 & 8.02 & 6.68 & 3.34 & 6.01 & 3.67 & 5.34 & 3.34 & 2.67 \\
Sodium $(\mathrm{Na})(\mu \mathrm{g} / \mathrm{g})$ & 36.07 & 16.70 & 19.37 & 34.07 & 22.04 & 16.70 & 19.04 & 21.54 & 22.04 & 12.69 \\
\hline
\end{tabular}

*ND = not detectable, ${ }^{*} *$ N.B. $($ Gul = Gulliver; Mar = Mare; Pur = Purdon; Rho $=$ Rhodes; Con 1, 2, $3=$ Connemara I, 2, 3; Tro = Troutbeck; Sto 1 = Storer 1)

Table 3. Phytoplankton taxa density (ind. $\mathrm{m}^{-3}$ ) recorded in the ten small montane reservoirs, Nyanga, Zimbabwe (2003).

\begin{tabular}{lcccccccccc}
\hline & \multicolumn{4}{c}{ Nyangombe River reservoirs } & \multicolumn{5}{c}{ Tsanga River reservoirs } \\
\hline Taxa & Udu & Rho & Mar & Pur & Gul & Con 1 & Con 2 & Con 3 & Tro & Sto 1 \\
Cyanophyta & 2510 & 24 & 265 & 41 & 1024 & 245 & 23 & 13313 & 491 & 199 \\
Euglenophyta & 0 & 0 & 267 & 0 & 16 & 6.5 & 0 & 0 & 1.5 & 3.1 \\
Chrysophyta-Chrysophyceae & 1972 & 26891 & 2134 & 1642 & 1719 & 173 & 22728 & 80 & 798 & 1988 \\
Chrysophyta-Bacillariophyceae & 8290 & 1537 & 2131 & 678 & 2205 & 1387 & 1602 & 469 & 643 & 992 \\
Pyrrophyta & 1297 & 1462 & 556 & 1216 & 720 & 1103 & 503 & 1163 & 81 & 148 \\
Chlorophyta & 11468 & 1524 & 12580 & 6756 & 6523 & 335520 & 45160 & 69920 & 7245 & 9539 \\
Total density (ind. $\mathrm{m}^{-3}$ ) & 25537 & 31438 & 17692 & 10332 & 11285 & 338434 & 70226 & 84946 & 9258 & 12870 \\
\hline
\end{tabular}

**N.B. $($ Gul = Gulliver; Mar = Mare; Pur = Purdon; Rho = Rhodes; Con 1, 2, 3 = Connemara 1, 2, 3; Tro = Troutbeck; Sto $1=$ Storer 1$)$

of metal ions $\mathrm{Na}, \mathrm{Mg}$ and $\mathrm{Ca}$ (Figure 3). Connemara I \& 3 dams were in the right lower quadrat and were characterized by higher nutrient concentrations of ammonium, total nitrogen, total phosphorus and total organic matter (Figure 3). The upper left quadrat had only site JUN P2 which was positioned close to the origin, thereby showing that it was not strongly associated with high $\mathrm{pH}$ and dissolved oxygen (Figure 3). The lower left quadrat had all the remaining sites which suggested that they were all similar in their overall water quality characteristics (Figure 3).

\section{Phytoplankton communities}

The phytoplankton community was not examined to species level but only the major groups were identified (Table 3). The major taxa identified included Cyanophyta, Euglenophyta, Chryospshaceae (Chrysophyta), Bacillariophyceae (Chrysophyta), Pyrrophyta and Chlorophyta. The least abundant taxa were the Euglenophyta being absent in reservoirs such as Udu, Rhodes, Purdon, Connemara $2 \& 3$. In the reservoirs it occurred its densities were extremely low (0.9-267 ind. $\left.\mathrm{m}^{-3}\right)$. Overall the Chlorophyta were the dominant taxa and were generally more abundant in the Tsanga River reservoirs. Highest overall densities were recorded in Connemara 1 (> 300000 ind. $\left.\mathrm{m}^{-3}\right)$, followed by Connemara $3\left(\approx 85000\right.$ ind. $\left.\mathrm{m}^{-3}\right)$ and $2\left(\approx 70000\right.$ ind. $\left.\mathrm{m}^{-3}\right)$. Densities were least in Troutbeck $(\approx 9200$ ind. $/ \mathrm{m} 3)$, Purdon $\left(\approx 10300\right.$ ind. $\left.\mathrm{m}^{-3}\right)$ and Gulliver $(\approx 11000$ ind. $\left.\mathrm{m}^{-3}\right)$ reservoirs. 


\section{Macrophyte communities}

A comprehensive assessment of the macrophyte communities of the 10 Nyanga reservoirs found 25 species of macrophytes (Table 4). Rhodes, Troutbeck and Storers 1 reservoirs had the highest number of species with 12 species each; and followed by Udu dam with 10 species while Mare and Purdon reservoirs had nine species each (Table 4). The three Connemara reservoirs had the least number of macrophyte species. The species diversity of macrophytes in the reservoirs followed a similar trend to that of species richness, where reservoirs having the highest number of species also have the most diverse plant community (Table 4). The reservoirs differed a lot in their aquatic vegetation characteristics. The most frequently encountered macrophyte species were Juncus effuses (80\%), Lagarosiphon major (60\%), Eleocharis sp. (50\%), and Cyperus maculates, Nymphaea caerulea, Potamogeton thunbergii Potamogeton octandrus all with a frequency of occurrence of (50\%). Rarely encountered macrophyte species with an occurrence of $10 \%$ included Wolffia arrhizam, Utricularia sp., Scirpus costatus, Nymphoides forbesiana, Isoetes aequinoctalis, Elatine triandra, Cyperus dichrostachys and Carex drakenbergensis.

Table 4. Macrophyte species occurring in ten small montane reservoirs, Nyanga, Zimbabwe (2003).

\begin{tabular}{|c|c|c|c|c|c|c|c|c|c|c|}
\hline \multirow[b]{2}{*}{ Species } & \multicolumn{5}{|c|}{ Nyangombe River reservoirs } & \multicolumn{5}{|c|}{ Tsanga River reservoirs } \\
\hline & Gul & Mar & Pur & Rho & Udu & Con 1 & Con 2 & Con 3 & Tro & Sto 1 \\
\hline $\begin{array}{l}\text { Carex cognata var. drakensbergensis } \\
\text { Cyperus dichrostachys }\end{array}$ & & & & + & & + & & & $\begin{array}{l}+ \\
+\end{array}$ & \\
\hline Cyperus maculatus & + & & + & & & & & & + & + \\
\hline Elatine triandra & & & & + & & & & & & \\
\hline Eleocharis sp. & + & + & + & & & & & & + & + \\
\hline Eriocaulon schweickerdtii & & + & & + & & & & & & + \\
\hline Hiomanthera sp. & & & & & & & & & & + \\
\hline Isoetes aequinoctalis & & & & & & + & & & & \\
\hline Juncus effuses & + & + & + & + & & + & + & + & + & \\
\hline Lagarosiphon major & + & & + & + & + & & & + & + & \\
\hline Najas sp. & & & & & + & & & & & \\
\hline Nitella $s p$. & & + & & & & + & & + & & + \\
\hline Nymphaea caerulea & + & + & + & + & + & & & & & \\
\hline Nymphoides forbesiana & & & + & & & & & & & \\
\hline Phragmites australis & & & & + & + & & & & & + \\
\hline Polygonum sp. & & & & + & + & & & & + & + \\
\hline Potamogeton octandrus & & + & + & + & + & & & & & + \\
\hline Potamogeton thunbergii & & + & + & + & + & & & & & + \\
\hline Ranunculus meyeri & + & + & & & + & + & & & & \\
\hline Scirpus costatus & & & & & & & & & + & \\
\hline Scirpus fluitans & & + & & & & & & & + & + \\
\hline Scirpus inclinatus & & & + & & & & & & + & + \\
\hline Typha latifolia & & & & + & + & & & & + & + \\
\hline Utricularia sp. & & & & & + & & & & & \\
\hline Wolffia arrhiza & & & & + & & & & & & \\
\hline Species richness & 6 & 9 & 9 & 12 & 10 & 5 & 1 & 3 & 12 & 12 \\
\hline Shannon-W (H) & 1.792 & 2.197 & 2.197 & 2.485 & 2.303 & 1.609 & 0 & 1.099 & 2.485 & 2.485 \\
\hline Simpson (1-D) & 0.8333 & 0.8889 & 0.8889 & 0.9167 & 0.9 & 0.8 & 0 & 0.6667 & 0.9167 & 0.9167 \\
\hline
\end{tabular}

**N.B. (Gul = Gulliver; Mar = Mare; Pur = Purdon; Rho = Rhodes; Con I, 2, 3 = Connemara 1, 2, 3; Tro = Troutbeck; Sto $1=$ Storer 1 ) 


\section{Zooplankton communities}

Twelve zooplankton species were identified as well as three taxonomic groups (Macrothricidae, Cyclopoida, and Calanoida) (Table 5). The Daphniidae had 8 species, Chydoridae had 2 species and Bosminidae and Sididae were each represented by one species each (Table 5). The number of species ranged from 4-7 species in the reservoirs hence no reservoir contained more than half the possible number of species. There was a single record of a Macrothricidae species, Macrothrix sp., only found in Udu dam. Ceriodaphnia reticulata, $C$. quadrangula, and Sinocephalus serrulatus only occurred in two reservoirs while Daphnia rosea and Diaphanosoma excisum occurred only in three reservoirs (Table 5). Strangely, there were no Calanoida sampled in the Nyangombe River reservoirs while the Cyclopoida were recorded in all the reservoirs as one of the most abundant taxa groups particularly in the reservoirs Gulliver, Mare, Rhodes, Udu and Connemara I.

\section{Discussion}

The water quality of the high altitude Nyanga reservoirs was of very good quality with some having conductivity close to that of distilled water. Nutrient concentrations were generally very low range and as a result the Nyanga reservoirs can be classified as oligotrophic and ultra-oligotrophic systems. The lack of significant urban developments around the reservoirs has helped significantly maintain near pristine water quality. The sediments were rather unusual with regards to the high levels of total phosphorus. In an earlier study, (Nduku and Robarts 1977) alluded to the same problem of high phosphorus content in the sediment of only one dam, Connemara No. 3. In this study done nearly 25 years later, the same situation still prevails. Processes that influence the binding of phosphorus are mediated by the iron-exchange process which is influenced by dissolved oxygen concentrations in the water.

Table 5. Zooplankton species densities (ind. $\mathrm{m}^{-3}$ ) in ten small montane reservoirs, Nyanga, Zimbabwe (2003).

\begin{tabular}{|c|c|c|c|c|c|c|c|c|c|c|}
\hline \multirow[b]{2}{*}{ Taxa } & \multicolumn{5}{|c|}{ Nyangombe River reservoirs } & \multicolumn{5}{|c|}{ Tsanga River reservoirs } \\
\hline & Gul & Mar & Pur & Rho & Udu & Con 1 & Con 2 & Con 3 & Tro & Sto 1 \\
\hline \multicolumn{11}{|l|}{ Daphniidae } \\
\hline Daphnia longispina & 270 & 400 & 230 & 700 & - & 40 & 430 & - & 530 & 230 \\
\hline D. laevis & 70 & 1370 & 270 & 1730 & - & 10 & - & - & - & - \\
\hline D. laevis gehelmd & 230 & 70 & 1000 & 930 & 130 & 10 & 1730 & - & 1500 & 600 \\
\hline D. rosea & - & - & - & - & - & - & - & 270 & - & 70 \\
\hline D. pulex & 130 & 130 & 30 & 370 & - & 30 & 300 & 600 & 330 & 970 \\
\hline Ceriodaphnia reticulata & - & - & - & - & 70 & - & - & - & - & - \\
\hline C. quadrangula & 30 & - & - & 70 & - & - & - & - & - & - \\
\hline Sinocephalus serrulatus & - & - & - & - & 70 & - & 130 & - & - & - \\
\hline \multicolumn{11}{|l|}{ Chydoridae } \\
\hline Alona sp. & - & 70 & - & - & 330 & 10 & 70 & 30 & - & 30 \\
\hline Chydrous sp. & 30 & - & - & 30 & 1330 & - & 30 & 70 & 100 & 1270 \\
\hline \multicolumn{11}{|l|}{ Bosminidae } \\
\hline Bosmina longirostris & 70 & 2330 & - & - & 1200 & 40 & - & 30 & - & 4070 \\
\hline \multicolumn{11}{|l|}{ Sididae } \\
\hline Diaphanosoma excisum & - & - & - & 30 & 70 & - & - & - & - & - \\
\hline Macrothricidae & - & - & - & - & 370 & - & - & - & - & - \\
\hline Cyclopoida & 2830 & 3730 & 130 & 1370 & 6200 & 250 & 300 & 130 & 170 & 1300 \\
\hline Calanoida & - & - & - & - & - & - & 270 & - & - & 70 \\
\hline No. of species & 7 & 6 & 4 & 7 & 7 & 6 & 6 & 5 & 4 & 7 \\
\hline Total density (ind. $\mathrm{m}^{-3}$ ) & 3660 & 8100 & 1660 & 5230 & 9770 & 390 & 3260 & 1130 & 2630 & 8610 \\
\hline
\end{tabular}


Typically the high dissolved oxygen levels in these reservoirs would evidently promote the binding of phosphorus to the $\mathrm{FePO}_{4}{ }^{3-}$ complex that can be easily trapped in the sediments. However what explains this high level of phosphorus in the sediments is still not clear. The construction of cottages around Connemara 3 and the subsequent construction of septic tanks was the main source of increased phosphorus loading in the reservoir. It was clearly a logical explanation for the discrepancy observed between the high phosphorus content of the sediments and the oligotrophic status of the water column. Little Connemara Dam (No. 3) is situated in a small dolerite catchment and when the dolerite rocks are weathered, there is release of large amounts of iron and manganese, but not a lot of calcium or carbonate (Nduku and Robarts 1977). The available phosphorus in the water then forms complexes with iron and also manganese and are then sequestrated to the bottom sediments.

Catchment characteristics have an important role in the limnological features of these reservoirs. In comparison with a similar studies carried out in Kenya on eight small high altitude lakes (Mwaura et al. 2002) and in Chile (Mühlhauser et al. 1995), the Nyanga reservoirs have lower nutrient loads, and significantly higher water transparency and lower turbidity. Temperatures in Kenya ranged from $15-21^{\circ} \mathrm{C}$ while the temperatures measured in Nyanga during sampling were all below $15^{\circ} \mathrm{C}$. Dissolved oxygen levels were at $100 \%$ saturation in the Nyanga reservoirs but much lower oxygen levels ranging from $23.4-33.6 \%$ were measured in the Kenya reservoirs with even periods of oxygen depletion. Conductivity and Total dissolved solids were much higher in the Kenya reservoirs ranging from $37-101 \mu \mathrm{S} / \mathrm{cm}$ and $29-82 \mathrm{mg} / \mathrm{l}$, respectively. The Chile lake is a moderately saline lake and is an endorheic system (Mühlhauser et al. 1995), Evidently, differences in catchment characteristics also clearly define the limnology of these high altitude reservoirs in Kenya, Chile and Nyanga. Most of the Nyanga reservoirs were under the protection of the State, while the remaining were under the management of different estates and this ensured that detrimental environmental activities were curbed.

The high altitude Nyanga reservoirs supported a fairly large diversity of macrophytes, with a fairly large divergence among the reservoirs. It is obvious that the high water clarity enabled the structured development of macrophytes communities, even at the deepest parts of some reservoirs like Connemara 3. This was supported by Secchi disc readings ranging from $1.5 \mathrm{~m}$ to $5.7 \mathrm{~m}$, which is indicative of high light penetration. Light limitation is a major factor limiting the distribution of submerged macrophytes in lentic systems (Wetzel 2001).

The phytoplankton was only identified to order so significant taxonomic resolution was lost. However an impression of the phytoplankton community was shown by the results obtained with the dominance of the Chlorophyta and Chrysophyta. This phytoplankton composition was consistent with systems of good water quality, low nutrient loading and $\mathrm{pH}$ that is not in the extremes of alkalinity or acidity (Wetzel 2001). Algal densities were also very low in all reservoirs when compared to other studies on small reservoirs that were more productive (Nhiwatiwa and Marshall 2007; Dalu et al. 2013). Measurements of algal biomass using chlorophyll $a$ concentrations showed results of less than $0.001 \mathrm{mg} / 1$ for nearly all the reservoirs. This is magnitudes lower than chlorophyll $a$ measurements from the Cleveland dam in Harare which is somewhat considered oligotrophic (Ndebele 2009). Our results were therefore consistent with the low nutrient status and productivity of all the Nyanga reservoirs.

Zooplankton densities were low (mostly $<1$ ind./L) and comparable to other oligo-mesotrophic systems such as Cleveland dam (Elenbaas and Grundel 1994). Small reservoirs on the Munwahuku River had much higher densities than the Nyanga reservoirs although species richness was actually comparable (Nhiwatiwa and Marshall 2007). The shallow Nyanga reservoirs and their prolific macrophyte vegetation have ideal littoral environment that perhaps contributes to the abundance of chydorid species in the reservoirs. The absence of Calanoida taxa from most reservoirs was intriguing as they typically occur in Zimbabwean reservoirs. The reasons for this were not clear but it could be that at time of sampling, the Calanoida populations were at their lowest or they are under severe predation pressure in these very clear waters.

It might be useful for a study that investigates the diet of the rainbow trout (Oncorhynchus mykiss) in these lakes especially the juvenile that are zooplanktivorous. Water clarity is very high. The diversity of the zooplankton occurring in 18 impoundments (altitudes range $1200 \mathrm{~m}-2270 \mathrm{~m}$ ) in Zimbabwe were assessed in 1983 (Green 1990). The species richness of crustaceans in the Nyanga reservoirs ranged from $4-7+$ (to include Calanoida and Macrothricidae not identified to species. Green (1990) carried out a zooplankton survey of small reservoirs at a range of altitudes and found 30 species of Rotifera and 20 species of Crustacea, and the mean numbers of species per lake were $5 \cdot 7$ rotifers and 4.5 crustaceans. According to the survey by Green (1990), Daphnia laevis was the most widespread and frequently dominant crustacean, while among the 
rotifers Keratella cochlearis was most frequently dominant, particularly in the lakes located at higher altitudes. The results of this study again confirm the dominance of $D$. laevis in concurrence with the findings of Green (1990).

High altitude reservoirs differ a lot in different regions of the world and there are also not many studies on small water reservoirs. In comparison with small farm reservoirs of comparable size in Zimbabwe (Nhiwatiwa and Marshall, 2007) in which over 40 zooplankton species were identified, zooplankton species richness is very low in Nyanga high altitude reservoirs. A study in Kenya on eight small montane reservoirs (Mwuara et al. 2002) revealed a zooplankton community that was composed mainly of crustaceans, rotifers and protozoa in. The zooplankton community of 21 montane water bodies were also studied in Brazil (Santos-Wisniewski et al. 2002). Like the Nyanga reservoirs, these waterbodies were densely colonized by macrophytes and were dominated by the Chydoridae, which typically inhabit the littoral zone living in association with macrophyte vegetation. The results was evidence of the importance of the littoral zone as favourable habitats Chydoridae species and thereby contributing to the overall diversity of cladocerans (Santos-Wisniewski et al. 2002).

Results of the cluster analysis (PCA) revealed groups of reservoirs with closely interrelated similarities which could be attributed to their being situated on the same river systems. The ordination analysis also identified the lowest locality (Udu) as the most divergent from the Nyangombe River system reservoirs and with the most typical tropical zooplankton community. Although all the Nyanga reservoirs are situated within the tropics, the high altitude of their location appeared to have excluded some of the most ubiquitous tropical African zooplankton species.

The reservoirs in Nyanga are located at high altitude and have relatively cool, ultra-oligotrophic waters. There are few indigenous fish species and the reservoirs are dominated by exotic rainbow trout (Oncorhynchus mykiss), which is the major angling species of a thriving tourist fishing activity. The rainbow trout mainly feeds on aquatic insects, crabs, frogs and other fish (Marshall 2011). A few specimens of the green-headed bream Oreochromis macrochir were seen in Udu dam during this study but they were struggling to survive in these freezing waters (pers. obs.). It is possible that an introduction of the fish into these waters but tilapia do not thrive at such low temperatures. The river sardine Mesobola brevianalis species was also introduced into the reservoirs in the 1970s from Lake Mutirikwe to provide food for the predatory trout but it appears the introduction was not a success since none were caught in this campaign.

The results of this study have given important insights into changes in some of the reservoirs that had been previously studied whilst new information was presented in other important ecosystems previously not studied. This work paves the way for a more detailed, seasonal sampling so that timelinked processes such as thermal stratification, can be fully understood for such reservoirs. Ecosystems such as the Nyanga reservoirs could provide useful indicators of change due to rising global temperatures through changes in their fauna and flora. It is also likely that these ecosystems are highly vulnerable and also responsive to climate change effects with serious consequences for their ecological integrity. Similarly, these pristine systems are also vulnerable to anthropogenic activities. The results of the study of Lake Hayq in the Ethiopian Highlands (Elizabeth et al. 1992), concluded that once was an exceptionally clear water lake with very low phytoplankton biomass was facing accelerated eutrophication because of human activity.

\section{Acknowledgements}

The project was funded by a VLIR-UOS grant from Belgium to support the Aquatic Ecology programme at the University of Zimbabwe. I would also like to extend my gratitude to the Biological Sciences Department and its staff for all the support that was rendered. Finally, many thanks to the visiting team from $\mathrm{KU}$ Leuven that came to Zimbabwe at the time.

\section{References}

Bronmark C, Hansson L. 1998. The biology of lakes and ponds. Oxford University Press. New York.

Brönmark C, Hansson L. 2002. Environmental issues in lakes and ponds: current state and perspectives. Environ. Conserv. $29 \quad$ (3): 290-307. doi: 10.1017/S0376892902000218

Canter-Lund H and Lund JWG. 1995. Freshwater Algae. Biopress Limited, England.

Christopher DK Cook (2004). Aquatic and Wetland Plants of Southern Africa Backhuys Publishers, Leiden, The Netherlands.

Dalu T, Clegg B, Nhiwatiwa T. 2013. Temporal variation of the plankton communities in a small tropical reservoir (Malilangwe, Zimbabwe). Transactions of the Royal Society of South Africa 68 (2): 85-96. doi: 10.1080/0035919X.2013.766280

Elenbaas PFM. 1994. Field and lab work on ecology in Zimbabwe. Nugi 825. University of Amsterdam.

Elenbaas PFM, Grundel C. 1994. Zooplankton composition and abundance in two impoundments in Zimbabwe. Hydrobiologia 272 (1): 265-275. doi: 10.1007/BF00006527 
Elizabeth K, Getachew T, Taylor WD, Zinabu GM. 1992. Eutrophication of Lake Hayq in the Ethiopian Highlands. Journal of Plankton Research 14(10): $1473-1482$. doi: 10.1093/plankt/14.10.1473

Ersal E. 1994. Inventory of small water bodies in the SADC region. ALCOM News 15: 12-16.

Farber L, Gilcreas FW, Edwards, GP, Taras, MJ. 1960. Standard methods for the examination of water and wastewater including bottom sediments and sludges. Eleventh edition. American Public Health Association, Inc., New York.

Fernando CH. 2002. A guide to Tropical Freshwater Zooplankton. Backhuys Publishers, Leiden. The Netherlands.

Gerber A, Cilliers CJ, van Ginkel C, Glen R. 2004. Easy identification of Aquatic Plants. Department of Water Affairs, South Africa.

Green J. 1990. Zooplankton associations in Zimbabwe. J Zool. 222(2): 259-283. doi: 10.1111/j.1469-7998.1990.tb05676.x

Greenberg RR. 1980. Simultaneous determination of mercury and cadmium in biological materials by radiochemical neutron activation analysis. Analytical chemistry 52(4): 676-679. doi: 10.1021/ac50054a020

Johnson N, Revenga C, Echeverria J. 2001. Managing water for people and nature. Science 92:(5519) 10711072 . doi: $10.1126 /$ science. 1058821

Jorge J, Contreras SSS, Merino-Ibarra SM, Nandini S. 2009. Seasonal changes in the rotifer (Rotifera) diversity from a tropical high altitude reservoir (Valle de Bravo, Mexico). J Environ B1ol. 30(2): 191-195.

Marshall B. 2011. The Fishes of Zimbabwe. Smithiana Monograph 3. The South African Institute for Aquatic Biodiversity, 190-191pp.

Mosello DR. 1984. Hydrochemistry of high altitude alpine lakes. Aquat Sci. 46(1): 86-99. doi: 10.1007/BF02538100

Mühlhauser HA, Hrepic N, Mladinic P, Montecino V, Cabrera S. 1995. Water quality and limnological features of a high altitude Andean lake, Chungani, in northern Chile. Revista Chilena de Historia Natural 68: 341-349.

Mwaura F, Mavuti KM, Wamicha WN. 2002. Biodiversity characteristics of small high-altitude tropical manmade reservoirs in the Eastern Rift Valley, Kenya. Lakes \& Reservoirs: Research and Management 7(1):1-12. doi: 10.1046/j.1440-1770.2002.00162.x
Ndebele MR. 2009. Primary production and other limnological aspects of Cleveland Dam, Harare, Zimbabwe. Lakes \& Reservoirs: Research and Management 14 (2): 151-161. doi: 10.1111/j.1440-1770.2009.00395.x

Nduku WK, Robarts RD. 1977. The effect of catchment geochemistry and geomorphology on the productivity of a tropical African montane lake (Little Connemara dam No. 3, Rhodesia). Freshwater Biol. 7 (1):19-30. doi: 10.1111/j.1365-2427.1977.tb01653.x

Nhiwatiwa T, Marshall BE. 2006. Seasonal and diurnal stratification in two small Zimbabwean reservoirs. Afr J Aquat Sci. 31 (2): 185-196. doi: 10.2989/16085910609503890

Nhiwatiwa T, Marshall BE. 2007. Water quality and plankton dynamics in two small reservoirs. Afr J Aquat Sci. 32 (2): 139-151. doi: 10.2989/AJAS.2007.32.2.5.202

Prescott GW. 1970. How to know the freshwater algae, $2^{\text {nd }}$ edition. Wm. C. Brown Company Publishers.

Rey J, Saint-Jean L. 1980. Branchiopodes. In: Flore et faune aquatiques de l'Afrique Sahelo-Soudanienne. Durand, J.R. and Leveque, C. (Eds), O.R.S.T.O.M, Paris, IDT 44, pp 307-332.

Sainty GR, Jacobs, SWL. 1988. Waterplants in Australia. Merritt Madden Printing, Sydney, Australia.416 pp.

Santos-Wisniewski MJ, Rocha O, Güntzel AM, Matsumura-Tundisi T. 2002. Cladocera and Chydroridae of high-altitude water bodies (Serra da Mantiquiera), in Brazil. Braz J Biol. vol. 62 no.4a São Carlos. doi: 10.1590/S1519-69842002000400016

Seaman ET, Kok DJ, Watson M. 1999. Cladocera. In: Day J.A., Stewart B.A., de Moor I.J. and Louw A.E. (Eds.), Guides to the freshwater invertebrates of Southern Africa: Crustacea. South African Water Research Commission, Pretoria.

Tartari GA, Tartari G, Mosello R. 1998. Water chemistry of high altitude lakes in the Khumbu and Imja Kola valleys (Nepalese Himalayas). Limnology of high altitude lakes in the Mt Everest Region (Nepal). Mem. Ist. ital. Idrobiol. 57: 51-76.

Thornton JA, Cotterill NG. 1978. Some hydrobiological observations on five tropical African montane impoundments. Transactions of the Rhodesia Scientific Association 59: 22-29.

Wetzel RG. 2001. Limnology: Lake and River Ecosystems, (Third Edition). Academic Press. 